\title{
IAMJ
}

INTERNATIONAL

AYURVEDIC

MEDICAL JOURNAL

\section{ROLE OF MANJISTHADI KSHARA BASTI IN MANAGEMENT OF AVASCULAR NECROSIS OF FEMORAL HEAD - CASE REPORT}

\author{
Chandu Metri ${ }^{1}$, Premalata Kamate ${ }^{2}$, Namrata Bhagaje ${ }^{3}$ \\ ${ }^{1}$ Consultant and Reader, Department of Panchakarma Krishna Ayurvedic Medical College Sankeshwar, Karnataka, \\ India \\ ${ }^{2}$ Consultant and Assistant Professor. Department of Prasooti and Stree Roga Krishna Ayurvedic Medical College, \\ Sankeshwar, Karnataka, India \\ ${ }^{3}$ Consultant and Assistant Professor. Department of Kayachikitsa Krishna Ayurvedic Medical College Ayurvedic \\ Medical College, Sankeshwar, Karnataka, India
}

Corresponding Author: akrmchandu@gmail.com

https://doi.org/10.46607/iamj17p5022021

(Published online: January 2021)

Open Access

(C) International Ayurvedic Medical Journal, India 2021

Article Received: 12/02/2021 - Peer Reviewed: 13/02/2021 - Accepted for Publication: 14/02/2021

Check for updates

\begin{abstract}
Avascular necrosis (AVN) of femoral head is the most common type of necrosis affecting the bones. Avascular necrosis of the bone is the death of osteocytes due to impaired blood supply. It usually affects people between 3050 years of age. It is associated with long term use of steroids, medications and excessive use of alcohol. It will be asymptomatic in early stages, as the condition progresses there will be gradual increase in pain and restricted range of movement of hip joint in end stage total joint destruction resulting in only surgical treatment. AVN treatment management aims at preserving the structural-functional integrity of bone and relief from the pain. Treatment modalities include administration of pain killers, anti-inflammatory medications (NSAIDS), core decompression (bone graft), modified Whitman or Colonna reconstruction, insertion of prosthesis and total joint replacement surgery are carried out as a treatment but causes financial burden and poor prognosis. Here we present a case of 19 years old male diagnosed with AVN of left hip joint. Clinical features in this case of AVN was merely correlated with Ashtivahasrotodushti (Bone channel-musculoskeletal system) and Majjagatavata and treated with different treatment
\end{abstract}


modalities explained in the context of Majjagatavata and Gambeeravatarakta such as Virechana and BastiChikitsa and treatment outcome was found to be encouraging in the terms of pain relief, relief from tenderness stiffness, flexible hip movement (improved gait) and no reoccurrence after 2 years in MRI.

Keywords: Avascular necrosis of hipbone, Majjagatavata, Gambeeravatarakta, Basti, Chikitsa, Ayurveda

\section{INTRODUCTION}

$\mathrm{AVN}$ is a condition effecting different bones as a result of transient or permanent deterioration of blood supply to the bones. Avascular necrosis (AVN) is osteonecrosis (dead bone) also known as Osteochondritis, Dissecans/ Chandlers Disease in young adults with $60 \%$ cases being bilateral presentation ${ }^{1}$ it occurs in 3 to $4 \%$ of patients receiving corticosteroids with most common site of involvement being femoral head, resulting in morbidity. AVN is one of the challenging hurdles being faced by orthopedic surgeons now days. It is a progressive disorder with surgical intervention as a prime treatment. Asti-Majjagata Vata, Vatavyadhi occurs due to vitiation of Vata Dosha present in Asthi Dhatu and Majja Dhatu. It presents with clinical futures as Bhedo Asthi Parvarnam (breaking type of pain in bone), Sandhishoola (Joint pain), Satata Ruk(Continuous nature of pain) etc. which co- relates with symptoms of AVN. Basti being a prime line of treatment in Vata Vikaras, Manjistadi Kshara Basti was administered in below case.

\section{Case Report:}

In December 2017, 19-year-old male student patient reported to Suraksha Ayurveda Chikitsalaya Ghataprabha, Karnataka, India with the complaints of pain and stiffness in left hip region which was associated with difficulty in doing daily normal activities. Pain would increase during cold climate, increased physical activities for which he previously October 2017 underwent consultation at neurology department KLE hospital Belagavi and oral medications were advised but no relief was seen. Further in same Hospital on $10^{\text {th }}$ November 2017 imaging diagnostic tool MRI of left hip joint revealed grade II avascular necrosis of left femoral head and further hip replacement was advised. Due to poor financial conditions patient refused surgery.
On examination in December 2017 patient presented with

- Gait: Trendelenburg sign was positive

- Third degree tenderness over left thigh

- Unable to lift the left limb

- Movements:

- Pain on the movement of left limb during flexion extension and lateral rotation

- Motor system:

- Crepitus: Absent

- Attitude of limbs: Flexed

- Nutrition: Moderate

○ Tone: Hypotonic in left limb

o Power: Normal

○ Involuntary movements: Absent

- Investigation:

- MRI of bilateral Hip Joint: Mentioned Subchondral sclerosis and focal geographical defect involving the head of left femur suggestive of GRADE II Avascular necrosis of Left Femoral Head.

\section{RESULTS AND DISCUSSION}

Considering the above history, clinical presentation and radiological findings treatment protocol was designed on principles of Ashtimajjagat vata ${ }^{2}$ and gambeeravataraktaChikitsa ${ }^{3}$. Complaint of painful and restricted range of movement of left limb indicates presence of Vata and Kaphadushtiin ashtivahasrotas ${ }^{4}$ (musculoskeletal system) and hence ManjisthadiKshar basti ${ }^{5}$ and drugs containing Tikta, Kashaya ${ }^{6}$, Raktashodhak ${ }^{7}$, Ashtiposhakgunas were administered accordingly. Since there is presence of Raktadushti in form of obstruction of blood supply to femoral head classical Virechan with Trivrutlehya was done. Basti is one among the Panchakarmas which clearly shows its efficacy in chronic conditions. 
With first course of Manjisthadiksharbasti pain relived $80 \%$ and limping was reduced indicating presence of revascularization of blood flow to femoral head. Further administration of TiktaRasayana oral Dravyas might have helped in bone nourishment. With this treatment patient showed overall well being physically in terms of relief in pain, stiffness and free range of movement and radiological evidence of absence of AVN in report in November 2018. And there is no evidence of pain or reoccurrence of any symptoms related to left hip joint till date.

Table 1: Treatment protocol

\begin{tabular}{|l|l|l|}
\hline Sl.no & Treatment administered & Duration \\
\hline 1. & Oral medications & 1 year \\
\hline 2. & Shodhan - Virechan & Once \\
\hline 3. & Manjisthadiksharbasti & Twice at the interval of 5 months \\
\hline
\end{tabular}

Table 2: Manjisthadi Ksharbasti ingredients

\begin{tabular}{|l|l|}
\hline Drug & Quantity \\
\hline Salt & $5 \mathrm{grams}$ \\
\hline Honey & $80 \mathrm{ml}$ \\
\hline Murchitatilataila & $60 \mathrm{ml}$ \\
\hline Kalka & $40 \mathrm{gms}$ \\
\hline Gomutra & $100 \mathrm{ml}$ \\
\hline Kwatha-Manjisthadikwath & $100 \mathrm{ml}$ \\
\hline Amla kaanji & $100 \mathrm{ml}$ \\
\hline
\end{tabular}

Table 3: Oral medications

\begin{tabular}{|l|l|}
\hline Sl.no & Name of the formulation \\
\hline 1 & Manjishthadikwath \\
\hline 2 & Kaishoreguggulu \\
\hline 3 & Arogyavardini Rasa \\
\hline 4 & Brihatvatachintamani \\
\hline 5 & Capsule. Flexy \\
\hline
\end{tabular}

Dosage

$15 \mathrm{ml}$ thrice in a day

1 tab thrice in a day

2 tabs thrice in a day

1 tab twice in a day

1 capsule thrice in a day

\section{CONCLUSION}

An Ayurvedic science has its own scientific principles of discipline of life and treatment principles. If one follows proper guidelines mentioned in literature one can find solutions for every disease which is difficult to manage with modern science. Manjisthadikshar Basti has got antagonist qualities towards Kapha due to Gomutra. Manjistha does the Raktaprasadana Karma due to its virtue of Tikta and Katurasa and Ushaguna. So, one can use Manjisthadikshar Basti along with oral drugs in the management of Avascular Necrosis. Further studies have to be conducted on large scale to know mode of action of Manjisthadi Kshara Basti in cases of Avascular necrosis.

\section{REFERENCES}

1. Kadlimatti SM, Subbanagouda P G, Sanakal A I, Deshpande M. Ayurvedic Management of Avascular Necrosis of the Femoral Head - A Preliminary Study. AYU 2008; $29: 154-160$

2. Charak samhita, Agnivesha, Acharya Yadavji Trikamji, Chaukhambha Sanskrit sansthan, Varanasi, 2004; pg.628

3. Charak samhita, Agnivesha, Acharya Yadavji Trikamji, Chaukhambha Sanskrit sansthan, Varanasi, 2004; pg.629

4. Chakradutta, Indradev Tripathi, Chaukhambha, Sanskrit sansthan, Varanasi, 2005; pg.455

5. Ashtanga Hridaya Sarvangasundari, Kunte, Chaukhambha Orientalia Varanasi, 2009; pg.620 
6. Charak Samhita, Agnivesha, Acharya Yadavji Trikamji, Chaukhambha Sanskrit Sansthan, Varanasi, 2004; pg. 652

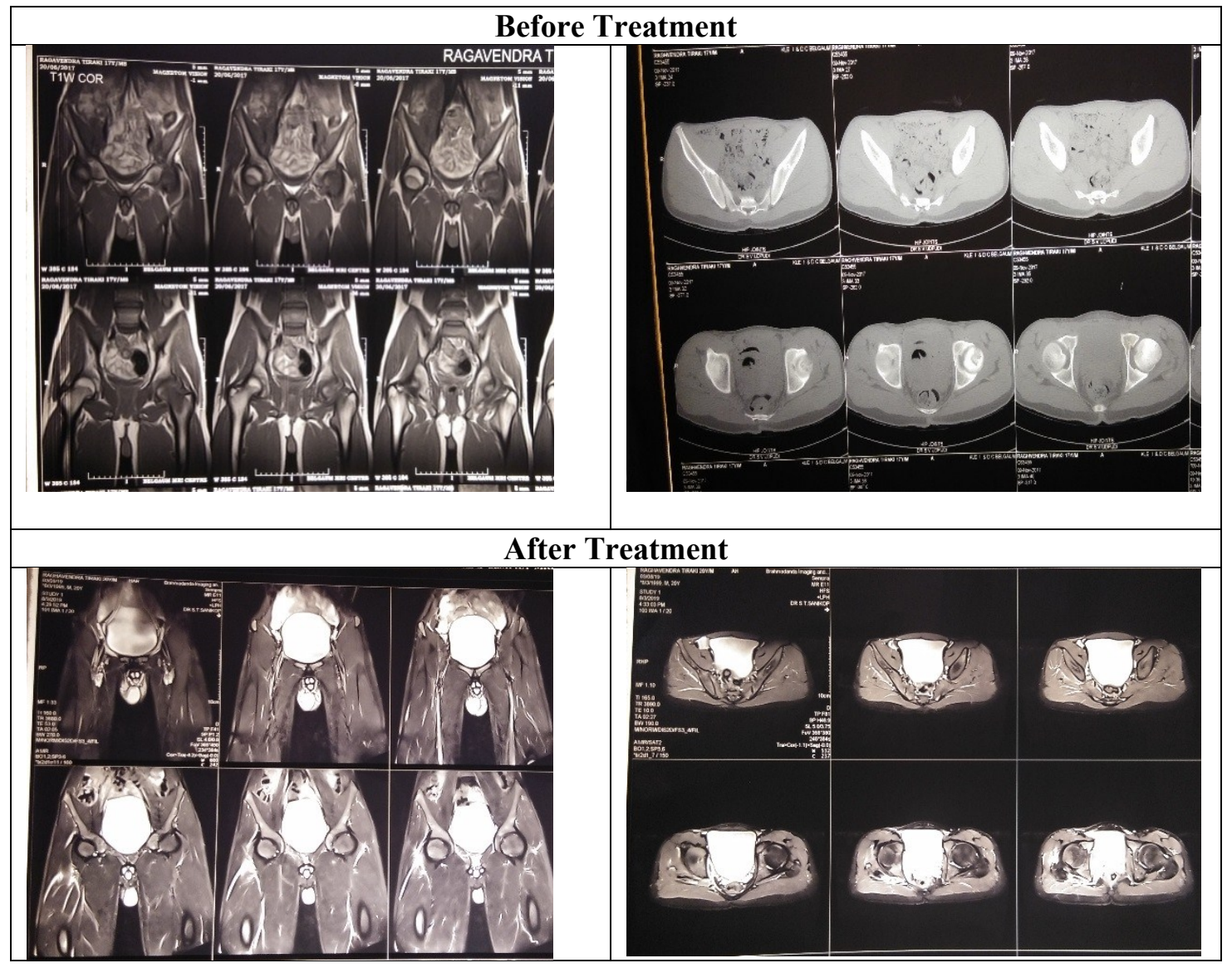

\section{Before Treatment Report}

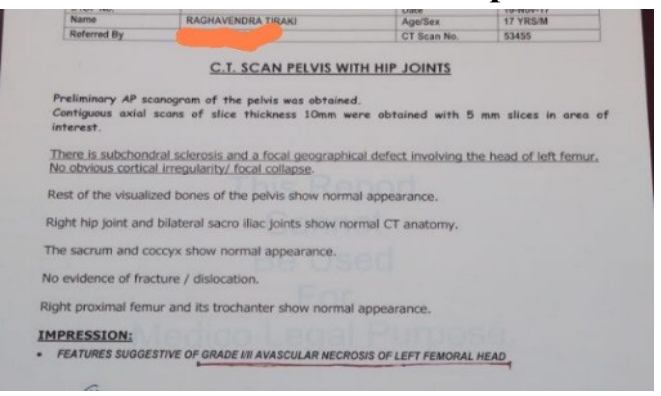

\section{After Treatment Report}

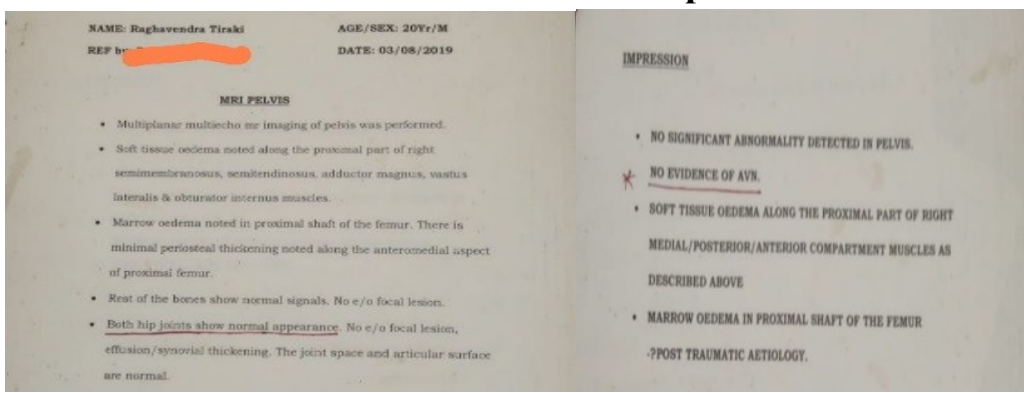

\section{Source of Support: Nil \\ Conflict of Interest: None Declared}

How to cite this URL: Chandu Metri et al: Role Of Manjisthadi Kshara Basti In Management Of Avascular Necrosis Of Femoral Head - Case Report. International Ayurvedic Medical Journal \{online\} 2021 \{cited January, 2021\} Available from: http://www.iamj.in/posts/images/upload/2763 2767.pdf 